\title{
Syneresis and chemical characteristics of fermented rice extract with probiotic bacteria and waxy maize starch
}

\author{
Kassia Kiss Firmino Dourado COSTA ${ }^{1}$, Paula Becker PERTUZATTI ${ }^{2}$, Tatianne Ferreira de OLIVEIRA ${ }^{1}$, \\ Márcio CALIARI ${ }^{1 \star}$, Manoel Soares SOARES JÚNIOR ${ }^{1}$
}

\begin{abstract}
The objective of this work was to elaborate fermented extracts using rice bran and broken rice grains (proportion 8:92) with probiotic bacteria and different concentrations of waxy maize starch (WMS) in order to obtain products with low level of syneresis and desirable physical-chemical characteristics, and to evaluate the content of phenolic compounds, antioxidant capacity and chemical composition of the extract selected and flavored with strawberry aroma and strawberry syrup. A randomized design was used with five treatments $\left(0,4,8,12\right.$ and $16 \mathrm{~g} 100 \mathrm{~g}^{-1}$ of WMS) and four replications. The fermented rice extract had increased soluble solids (from 12.97 to $14.23{ }^{\circ}$ Brix) and total acidity (from 0.29 to $0.30 \mathrm{~g} 100 \mathrm{~g} \mathrm{~g}^{-1}$ ), whereas total soluble

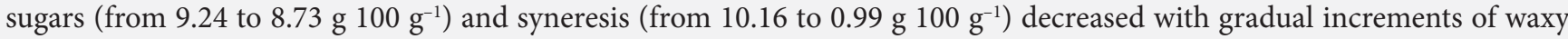

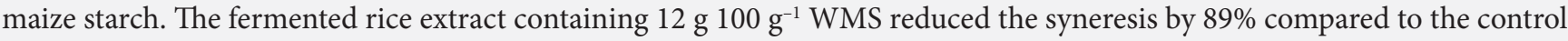

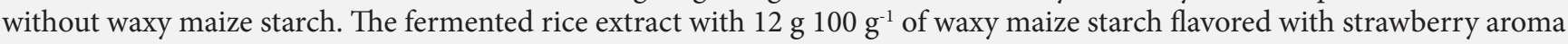
and strawberry syrup shows high nutritional value, antioxidant capacity, content of total phenolic compounds, and marketing potential, particularly for consumers with special needs, such as those allergic to lactose or soybean proteins, as an alternative food ready for consumption.
\end{abstract}

Keywords: Oryza sativa (L.); phenolic compounds; antioxidant capacity; by-products; scanning electron microscopy.

Practical Application: Creating high-quality product to increase food choices for consumers intolerant to milk or soy.

\section{Introduction}

Rice is one of the main food crops, and in recent years, the annual global production was around 470 million metric tons and should reach in 2014/15 a record of 481 million tons (United States Department of Agriculture, 2014). Consequently, by-products from rice processing such as bran and broken grains are abundant and readily available. These are important sources of food components, such as starch, which is responsible for over $90 \%$ of the broken grains, as well as other components including proteins and lipids, fibres, minerals and vitamins (Shih, 2012).

Broken rice is used for the production of alcoholic and non-alcoholic beverages. In some oriental countries, rice based beverages, known as "milk" extracts or rice drinks are heavily marketed. These products have mild and slightly sweet flavor, a result of the hydrolysis of starch into maltose and other sugars by the action of enzymes. This technology is viable, favoring its production in regions where rice production is significant, diversifying the consumption of this cereal (Jaekel et al., 2010).

In the West, by contrast, drinks obtained from rice extracts are a new alternative for consuming healthy products with desirable nutritional characteristics. Moreover, they provide an option to replace dairy products and soy products, since many people are intolerant to lactose and have allergie to soy proteins (Fagundes, 2012). On the other hand, yogurt and fermented milks represent the main category among foods with added probiotics (Cruz et al., 2013).

The search for drinks and foods that meet demand from health-conscious consumers has a direct impact on food industry, which aims to provide new products with attractive functional features, convenience and adequate sensory quality (Bezerra et al., 2015). Therefore, it is important to invest in research and development of products that resemble the traditional ones.

The fermented rice extract with probiotic bacteria and different concentration of waxy maize starch presented rheological behavior similar to the traditional yogurts (Costa et al., 2016). Waxy maize starch have higher maximum viscosity and lower tendency to retrogradation than the normal maize starch, causing less water loss and it has been used to improve the rheological properties of fermented plant extracts type (Weber et al., 2009).

In this context, the objective of this work was to elaborate fermented extracts using rice bran and broken rice grains (proportion 8:92) with probiotic bacteria and different concentrations of waxy maize starch in order to obtain products with low level of syneresis and desirable physical-chemical characteristics, and to evaluate the content of phenolic compounds, antioxidant capacity and chemical composition of the extract selected and flavored with strawberry aroma and strawberry syrup. 


\section{Material and methods}

\subsection{Material}

Rice by-products were donated by the company Arroz Cristal, located in Aparecida de Goiania, Goiás, Brazil; the waxy maize starch (WMS) by the company Fecularia Bela Vista, from Bela Vista de Goiás, and the artificial strawberry flavor (Gemacom, R 201 110) by the company Leite \& Cia., located in Goiania. The starter culture Rich ${ }^{\circledR}$, consisting of strains of Streptococcus thermophilus, Bifidobacteria spp. and Lactobacillus acidophilus, the crystal sugar and fresh strawberries were purchased in the local market.

\subsection{Preparation of the extract of rice bran and broken rice grains}

Rice bran was maintained for $3 \mathrm{~min}$ in microwave oven (Panasonic NN-ST652W, Manaus, Brazil) at 900W (Abdul-Hamid et al., 2007), roasted $\left(110^{\circ} \mathrm{C}\right.$ for $\left.10 \mathrm{~min}\right)$ in batches of $500 \mathrm{~g}$. The product was then sifted through a $0.595 \mathrm{~mm}$, packed in laminated bags (polyethylene/nylon/polyethylene) under vacuum, and stored at $-18{ }^{\circ} \mathrm{C}$ until processing.

The rice extract was prepared following the method proposed by Soares et al. (2010), the broken grains and the roasted rice bran were mixed in the same ratio as the whole rice composition ( $92 \%$ broken grains and $8 \%$ rice bran), the mixture was added water in the proportion of $1 \mathrm{~kg}$ of mixture to $3 \mathrm{~L}$ of water and boiled in an industrial stove. Disintegration of the baked product was carried out in water (1:1) for $3 \mathrm{~min}$ in blender (Siemsen, LSB 25, Brusque, Brazil) until obtaining a homogeneous mixture. The permeated was then sieved, and the opaque and whitish liquid was named water soluble extract.

\subsection{Development of natural and flavored fermented rice extracts}

The extract of rice was heated to $\pm 60^{\circ} \mathrm{C}$ in water bath, added WMS.

A completely randomized design was used, with five

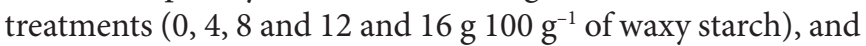
four original repetitions, totaling 20 experimental units. It was added sugar $\left(100 \mathrm{~g} \mathrm{~L}^{-1}\right)$, and the temperature was raised to $85^{\circ} \mathrm{C}$ for $5 \mathrm{~min}$. Extracts were then cooled down to $45^{\circ} \mathrm{C}$, added a dairy culture ( $400 \mathrm{mg} \mathrm{L}^{-1}$ ), transferred to $50 \mathrm{~mL}$ plastic pots with screw caps previously sanitized in a sodium hypochlorite solution $\left(200 \mathrm{mg} \mathrm{L}^{-1}\right)$ for $15 \mathrm{~min}$. Samples were incubated in B.O.D (Tecnal, TE-4013, Piracicaba, Brazil) at $45^{\circ} \mathrm{C}$ up to $\mathrm{pH} 4.5$, measured with a potentiometer and stored under refrigeration $\left(5 \pm 1{ }^{\circ} \mathrm{C}\right)$ until the analysis.

The fermented rice extracts were analyzed for syneresis content. The extract that showed the highest reduction of the syneresis proportionally to the added amount of starch was selected and flavored with artificial strawberry aroma (8 mg $100 \mathrm{~g}-1)$ and strawberry syrup (300g L-1), as described by Miranda et al. (2012); and characterized for chemical composition, total phenolic and antioxidant capacity. All analyses were performed in triplicate.

\subsection{Syneresis and physico-chemical characterization}

The percent of syneresis after $48 \mathrm{~h}$ was determined according to the method proposed by Amatyakul et al. (2006). Samples were analyzed for total soluble solids at $20^{\circ} \mathrm{C}$ in refractometer (Reichert, Handheld Refractometer, New York, United States), and the total acidity by titration with $0.1 \mathrm{M} \mathrm{NaOH}$, according to methodologies proposed by the Association of Official Analytical Chemists (2012); and total soluble sugar content (TS) according to Dische (1962).

\subsection{Scanning electron microscopy}

The micrographs of fermented rice extract and WMS were obtained in a scanning electron microscope (JEOL JSM-6610, Tokyo, Japan), equipped with EDS (Thermoscientific Spectral Imaging NSS). The sample was previously lyophilized (Liobras, LP 820, São Carlos, Brazil), and maintained in desiccator until fixation with double-sided tape in aluminium support, and metallized with a carbon layer coating system (Jeol, JEE-420, Tokyo, Japan). The images were captured in the magnitudes of $1,000 \mathrm{X}$ for fermented rice extract and 2,500X for WMS.

\subsection{Chemical composition}

The moisture content was determined in a vacuum oven (Tecnal, TE-395, Piracicaba, Brazil); total nitrogen by the micro-Kjeldahl method in nitrogen distiller (Tecnal, TE-0363, Piracicaba, Brazil); lipids in Soxhlet apparatus (Tecnal, TE-044, Piracicaba, Brazil); ashes by incineration in muffle furnace (EDG, Oven Economic, São Carlos, Brazil); all according to the methods recommended by Association of Official Analytical Chemists (2012).

\subsection{Total phenolic and antioxidant capacity}

The extraction was carried out according to Hung et al. (2009), with adaptation (ultrasonic bath to improve the extraction and reduce the aliquot of sample and solvent). Samples were potted in $50 \mathrm{~mL}$ amber bottles and maintained in freezer until analysis. The Total phenolic compounds were determined according to a modified method of Singleton et al. (1999).

The absorbance value was read in a spectrophotometer (BEL Photonics, S 2000 UV, Osasco, Brazil) at $760 \mathrm{~nm}$ and the results expressed in $\mathrm{mg}$ of gallic acid equivalents per gram of sample (mg GAE g ${ }^{-1}$ ) on dry basis.

Antioxidant capacity was measured by two methods, DPPH and ABTS radical cation, to determine which one best detects the response. The first was performed according to a modified method of Brand-Williams et al. (1995), and the second was carried out following the adapted method of Re et al. (1999). Both results were expressed in $\mu \mathrm{mol}$ of Trolox equivalents (TE) $\mathrm{g}^{-1}$.

\subsection{Experimental design and analysis of results}

The results were analyzed by Anova and regression analysis, by the softwares Statistica and Excel version 2010 (Microsoft Excel 2010, Redmond, USA). 
The regression analysis will allow to verify if the waxy starch content is related to the response variables. To understand these relationships it is necessary to establish mathematical models, which help to understand how the behavior of one variable can change the behavior of another.

\section{Results and discussion}

\subsection{Syneresis and physico-chemical characteristics}

The mathematical models for syneresis and physico-chemical characteristics were significant and explain 78 to $97 \%$ of the responses, with the effects of WMS level being quadratic for syneresis and total soluble sugar, and cubic for total acidity and total soluble solids (Table 1 ).
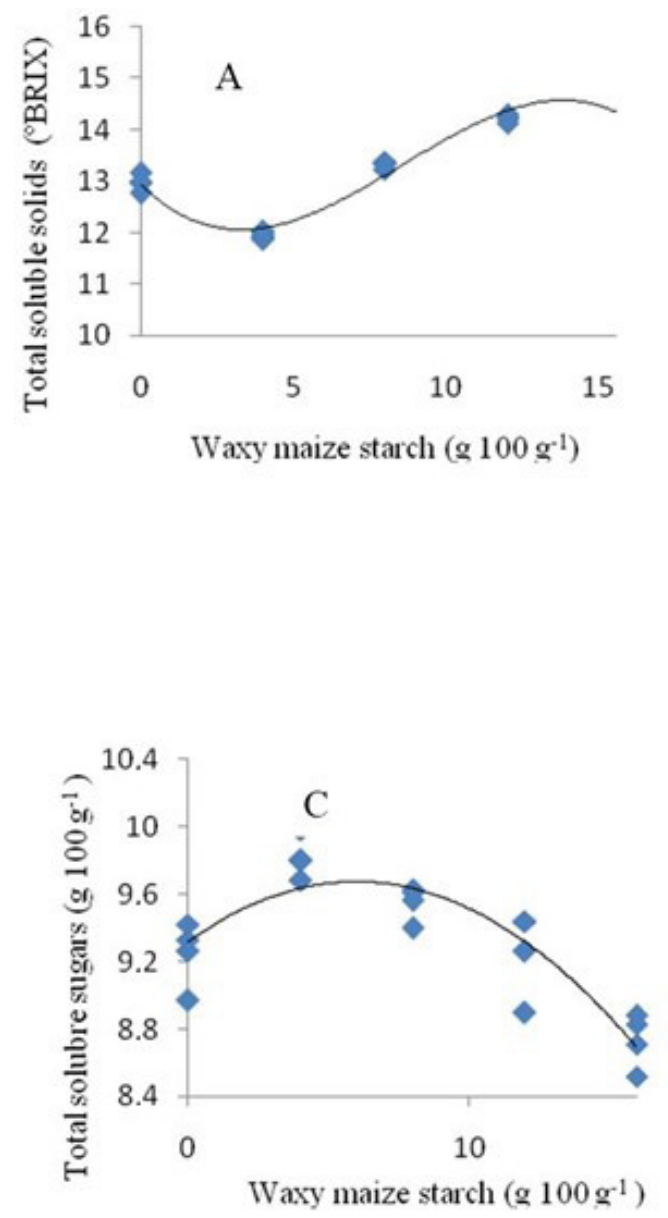

The behavior of total soluble solids and total acidity as a function of WMS content resembled a sigmoid curve (Figure 1A e 1B),

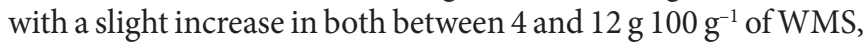

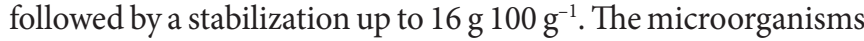
added had an influence on the product composition, by using the food as a substrate for their metabolism, producing enzymes capable of hydrolyzing starch components, yielding dextrins (mixture of low molecular weight oligosaccharides $(+)$ maltose, and $\mathrm{D}(+)$ - glucose) and acids, which are water soluble and contributed to the variations in the total soluble solids content; result observed also by Morrison (2005).

In this study, the starch hydrolysis occurred, evidenced by the increment in soluble solids, except between fermented

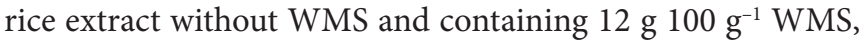
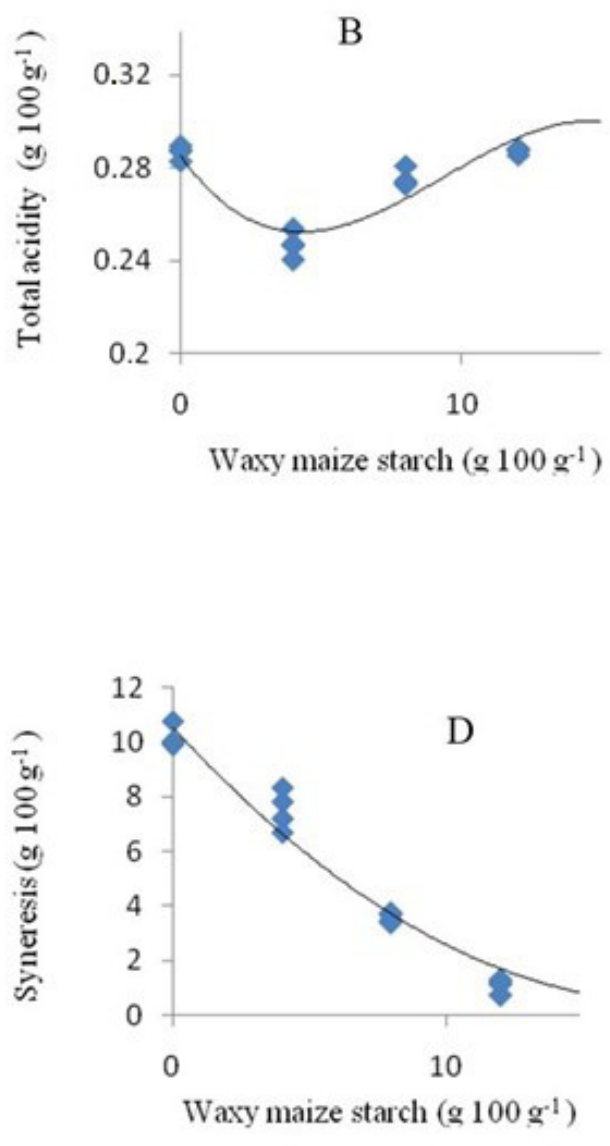

Figure 1. (A) Total soluble solids; (B) total acidity; (C) total soluble sugars and (D) syneresis of fermented rice extracts (8:92 - rice bran: broken rice grains), respectively $\mathrm{y}_{1}$ to $\mathrm{y}_{4}$, as a function of the concentration of waxy maize starch (x).

Table 1. Adjusted regression models, significance level $(\mathrm{p})$ and coefficient of determination $\left(\mathrm{R}^{2}\right)$ for total soluble solids, total acidity, total soluble sugars and syneresis ( $\mathrm{y}_{1}$ to $\mathrm{y}_{4}$, respectively) of fermented rice extracts prepared with rice bran and broken rice grains (8:92) as a function of the concentration of waxy maize starch $(\mathrm{x})$.

\begin{tabular}{llll}
\hline \multicolumn{1}{c}{ Parameter } & \multicolumn{1}{c}{ Model } & $\mathrm{p}$ & $\mathrm{R}^{2}$ \\
\hline Total soluble solids & $\mathrm{y}_{1}=12.9338-0.5806 \mathrm{x}+0.1097 \mathrm{x}^{2}-0.0043 \mathrm{x}^{3}$ & 0.000001 & 0.95 \\
Total acidity & $\mathrm{y}_{2}=0.2852-0.0170 \mathrm{x}+0.0026 \mathrm{x}^{2}-0.0001 \mathrm{x}^{3}$ & 0.000001 & 0.88 \\
Total soluble sugars & $\mathrm{y}_{3}=9.3196+0.1188 \mathrm{x}-0.0099 \mathrm{x}^{2}$ & 0.000001 & 0.78 \\
Syneresis & $\mathrm{y}_{4}=10.5536-1.0881 \mathrm{x}+0.0293 \mathrm{x}^{2}$ & 0.000001 & 0.97 \\
\hline
\end{tabular}


because the lowest WMS concentration did not contribute to the hydrolysis reaction. Among other treatments, hydrolysis increased gradually with the increment of WMS, up to concentrations of

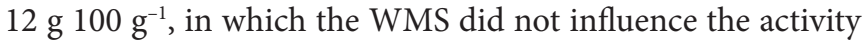
of hydrolytic enzymes.

Oliveira et al. (2008) found total soluble solids values of yogurt ranging from 15.3 to $18.2^{\circ} \mathrm{Brix}$, higher than those found in this study. Results explained by the chemical composition of the milk, which is richer in soluble solids than the extract of rice bran and broken grains.

The total acidity was lower in the formulation with $4 \mathrm{~g} 100 \mathrm{~g}$-1207 WMS (Figure 1B) as effect of the addition of starch, the content of simple sugars (glucose + fructose) from the added sucrose is reduced due to the presence of competing starch with water present, this makes it difficult to break the bonds and consequent production of acid by the crop. With the addition of WMS in higher concentrations, the total acidity is increased due to the increased availability of maltose and glucose produced by the breakdown of the starch by enzymes produced by the added bacteria. Therefore, the total acidity is also related to the type of solid added (milky or not), and with the activity of the culture responsible for the fermentation, which has high influence on the quality attributes of the fermented dairy products and constitute a limiting factor to their acceptance (Thamer \& Penna, 2006).

Initially, the total acidity of fermented rice extract containing

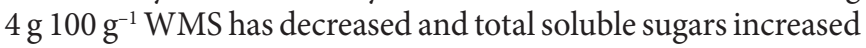
compared to the sample without WMS. Then, a reduction of total soluble sugars levels and increase of total acidity occurred when increasing WMS (Figure 1B, C). This trend can be explained by the metabolism of inoculated microorganisms that used sugars and WMS for the production of acids such as lactic, the SCFA and acetic, among others, causing increase in total acidity and decrease in total soluble sugars (Prassad et al., 2013). Coda et al. (2012), working with fermented beverages "yogurt type" obtained from various cereals, observed in the sample made of rice flour

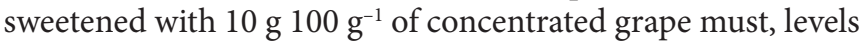
of sugars (glucose and fructose) of $5.61 \mathrm{~g} 100 \mathrm{~g}^{-1}$, lower than

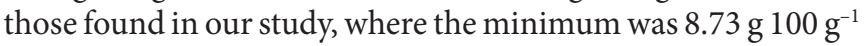

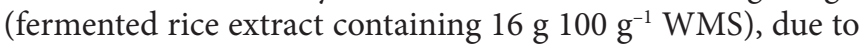

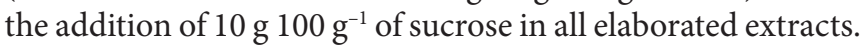
The sweetness of some mono and disaccharides is one of its most recognized and pleasant functional properties and the intensity of sweet taste of a food vary with the type of sugar and its concentration in the food (Ribeiro \& Seravalli, 2007). In this context, the products to be fermented must have the appropriate sugar content, so that at the end of fermentation, they have pleasant taste to the human palate. Therefore, the results of total soluble sugars found in the products were favorable, once fermentation did not significantly reduce the content of sugar added.

The addition of WMS decreased the syneresis index

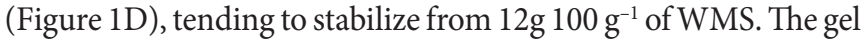
formed after starch gelatinization, stored under refrigeration has a tendency to release water due to retrogradation, phenomenon named syneresis. This is related to the starch composition, as it is known that higher levels of amylopectin, as in the case of WMS, form translucent gels with lower propensity to retrogradation
(Singh et al., 2007). In this work, the gel formed almost no retrograded, especially in samples with higher concentrations of WMS. The higher the presence of WMS in the formulations, proportionally lower was the content of rice starch with higher amount of amylose, which is responsible for higher retrogradation and water loss.

Lobato-Calleros et al. (2014) in a study with smoothie

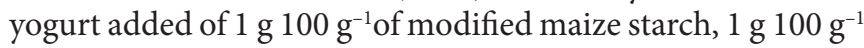
of native maize starch and control without starch, obtained

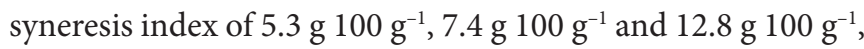
respectively, measured $24 \mathrm{~h}$ after preparation. These values corroborate with those of the present study, where the fermented rice extract without WMS showed syneresis of $10.16{\mathrm{~g} 100 \mathrm{~g}^{-1}}^{-1}$

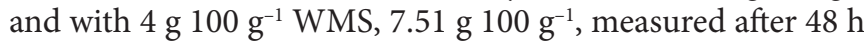
of preparation, and food matrices were totally different since those authors worked with yogurt from reconstituted cow's milk.

Prassad et al. (2013), working with yogurt added of $2 \mathrm{~g} 100 \mathrm{~g}^{-1}$ of modified WMS after one day of preparation, obtained respectively, 3.66 and $3.54 \mathrm{~g} 100 \mathrm{~g}^{-1}$ with approximately $3 \%$ reduction in the syneresis index, concluding that the modified WMS contributed to reduce the water loss by the gel network in the product. In this study, fermented rice extract

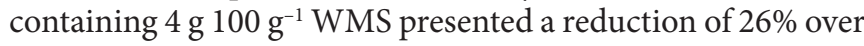
the fermented rice extract without WMS, difference that might be associated with the use of a non-dairy base, as well as the higher amount of WMS. Syneresis can be influenced by the preparation conditions, besides the chemical composition, $\mathrm{pH}$, incubation temperature, and storage conditions of the product (Dannerberg \& Kessler, 1988), and tends to decrease with higher amounts of solid matter in the fermented product (Jaros et al., 2002). According to results obtained, the fermented rice extract

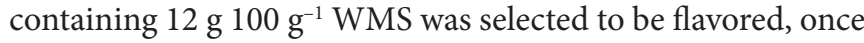
it showed $89 \%$ reduction in syneresis, high total soluble solids content, and higher total soluble sugar content.

\subsection{Scanning electron microscopy}

Scanning electron microscopy (Figure 2A, E), showed that fermented rice extract had different structures depending on the WMS concentration. An apparently viscous matrix covers a large amount of starch granules with the characteristic polygonal format of WMS (Figure 2F).

The matrix surrounding the WMS granules (Figure 2B, E) is probably constituted by proteins and gelatinized rice starch, once it has lower gelatinization temperature, around $63{ }^{\circ} \mathrm{C}$ (Bartz et al., 2012), than WMS which is near $75^{\circ} \mathrm{C}$ (Weber et al., 2009). Rice starch granules were not observed in fermented rice extract without WMS (Figure 2A, E), probably due to the gelatinization of the most part during the heat treatment for preparing the fermented extracts $\left(85^{\circ} \mathrm{C}\right.$ for $5 \mathrm{~min}$ ).

\subsection{Antioxidant capacity and chemical composition of flavored fermented rice extract}

The antioxidant capacity measured after $30 \mathrm{~min}$ by the DPPH radical method was $44 \%$, after $24 \mathrm{~h}$ the antioxidant capacity measured was $51 \%$, lower than the results measured 


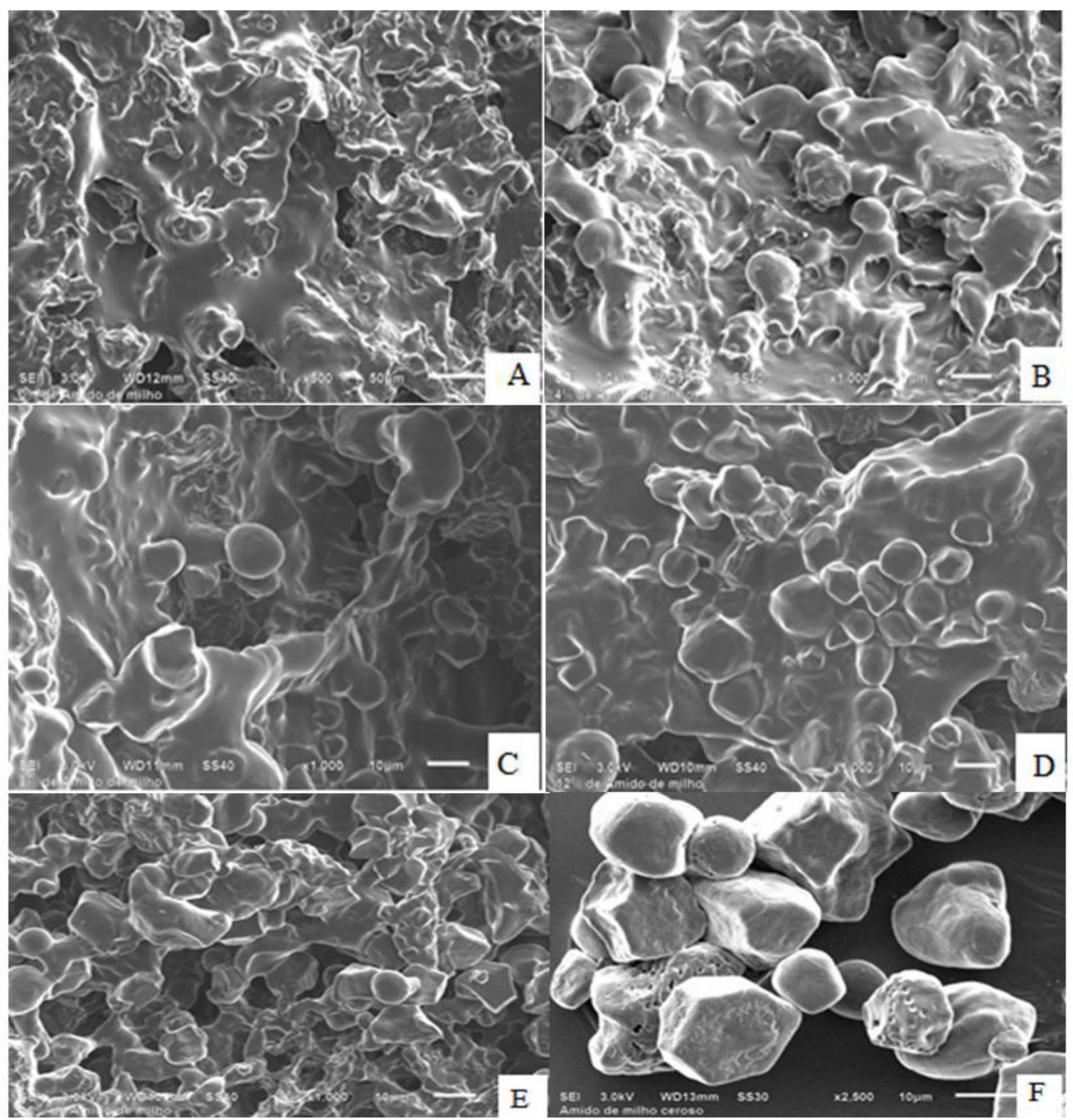

Figure 2. Photomicrographs of fermented rice extracts prepared with rice bran and broken rice grains (8:92) at concentrations of $0 \mathrm{~g} 100 \mathrm{~g}^{-1}$

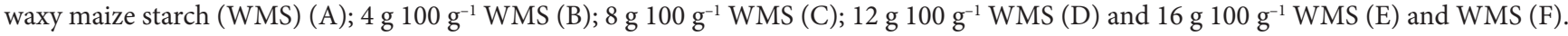

by the technique of ABTS (Table 2), showing that this method was more efficient to quantify the antioxidant capacity of flavored fermented rice extract selected. The value of ABTS found in fermented rice extract selected and flavored with strawberry aroma and strawberry syrup $\left(25.99 \mu \mathrm{mol} \mathrm{Trolox} \mathrm{g}^{-1}\right.$ sample) can be compared with grape of variety BRSLorena (27 $\mu$ mol Trolox $~^{-1}$ sample) (Barcia et al., 2015), this grape is used for the production of white wine, a product known for its antioxidant capacity.

Zhao \& Shah (2014), working with fermented soymilk, obtained $16.9 \%$ inhibition of $\mathrm{DPPH}_{30 \min }$ and total phenolic compounds of $47.4 \mathrm{mg} \mathrm{GAE} 100 \mathrm{~g}^{-1}$, lower than those found in the fermented rice extract selected and flavored with strawberry aroma and strawberry syrup of the present study (Table 2).
Table 2. Antioxidant capacity measured by the methods DPPH (30 min and $24 \mathrm{~h}$ ) and ABTS, total phenolic compounds, moisture (wet basis), protein, lipids and ash (dry basis) of fermented extract of rice bran and

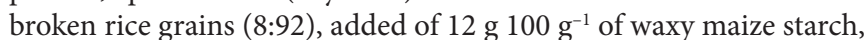
and flavored with strawberry aroma and strawberry syrup.

\begin{tabular}{lc}
\hline \multicolumn{1}{c}{ Parameter } & Means \pm standard deviation \\
\hline ABTS $^{1}$ & $25.99 \pm 0.27$ \\
DPPH $_{(30 \mathrm{~min})}^{1}$ & $14.47 \pm 0.45$ \\
DPPH $_{(24 \mathrm{~h})}^{1}$ & $12.77 \pm 0.27$ \\
Total phenolic compounds $^{2}$ & $126.25 \pm 1.89$ \\
Moisture $^{3}$ & $67.44 \pm 0.26$ \\
Protein $^{4}$ & $2.33 \pm 0.00$ \\
Lipids $^{4}$ & $0.19 \pm 0.00$ \\
Ash $^{4}$ & $0.63 \pm 0.05$ \\
\hline
\end{tabular}

${ }^{1} \mu \mathrm{mol}$ Trolox g ${ }^{-1}$ sample; ${ }^{2} \mathrm{mg}$ GAE $100 \mathrm{~g}^{-1} ;{ }^{3} \mathrm{~g} 100 \mathrm{~g}^{-1}$ (wet basis); ${ }^{4} \mathrm{~g} 100 \mathrm{~g}^{-1}$ (dry basis). 
Illupapalayam et al. (2014) found 57\% inhibition in traditional milk yogurt using the DPPH method, higher value than obtained in this work (Table 2). These authors consider the metabolic activity of the fermented microorganism important for the antioxidant capacity of the product. Many factors can contribute to the antioxidant capacity of the products, including the processing method and ingredients used as well as the probiotic culture inoculated. Total phenolic compounds are largely the responsible for the antioxidant capacity of the fermented extract. According to studies by Shori \& Baba (2014), who studied total phenolic content in cow or camel milk yogurt and found approximately 3 and 6 mg GAE 100 g-1 respectively, the total phenolic content in milk can be explained by the formation and / or further degradation of polymeric phenols during fermentation by yogurt bacteria. These values are lower than the present study. Butsat \& Siriamornpun (2010) stated that the antioxidant capacity in the Thai rice fractions (husk, bran and endosperm) depends on the amount of phenolic compounds present in each fraction.

The level of moisture of the fermented rice extract selected and flavored with strawberry aroma and strawberry syrup (Table 2) was 15\% lower than that found by Soares et al. (2010) in brown rice extract added of passion fruit pulp and crystal sugar. This difference is mainly related to the presence of WMS in the fermented rice extract selected and flavored with strawberry aroma and strawberry syrup of the present study.

Ye et al. (2013), working with yogurt from cow's milk and "yogurt" from black soybeans, obtained higher levels of proteins,

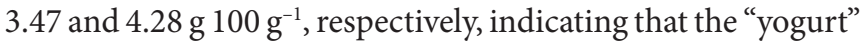
from plant extract is richer in protein than the similar from cow's milk, and the protein content in the fermented rice extract selected and flavored with strawberry aroma and strawberry syrup of this study (Table 2) was 33\% lower, probably due to the presence of milk proteins. Those authors also found 2.66 and

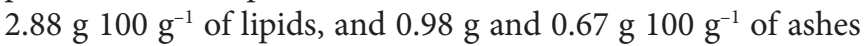
for the milk and black soybean yogurt, respectively, therefore fattier than the fermented rice extract selected and flavored with strawberry aroma and strawberry syrup of this study.

Sengül et al. (2014), working with yogurt flavored with

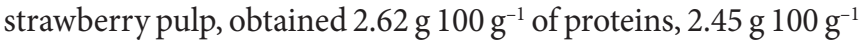

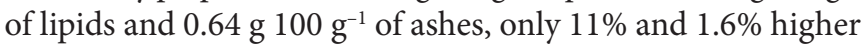
than the fermented rice extract selected and flavored with strawberry aroma and strawberry syrup (Table 2), and only small differences between the products of plant and dairy bases. According to the Brazilian Table of Food Composition (Universidade de São Paulo, 2015), UHT cow milk has $2.97 \mathrm{~g}$ of protein while brown rice cooked for $28 \mathrm{~min}, 2.30 \mathrm{~g}$. The lipid content of the cow's milk is around $3.04 \mathrm{~g}$, in rice, this nutrient is in the range of $0.74 \mathrm{~g}$. In relation to ash content, cow's milk has around $0.79 \mathrm{~g}$ brown rice cooked $0.22 \mathrm{~g}$. This demonstrates the differences found in the product of the present study in relation to traditional yogurts (from the fermentation of cow's milk).

\section{Conclusion}

The increase of waxy maize starch in the fermented rice extract decrease syneresis and the content of total soluble sugars, and increase the total acidity and the content of soluble solids.

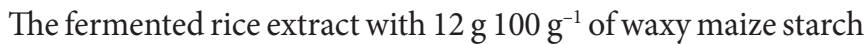
flavored with strawberry aroma and strawberry syrup shows high nutritional value, antioxidant capacity, content of total phenolic compounds, and marketing potential, particularly for consumers with special needs, such as those allergic to lactose and soybean proteins, as an alternative food ready for consumption.

\section{Acknowledgements}

The authors thank the CAPES for the scholarship, and the companies Arroz Cristal, Fecularia Bela Vista and Leite \& Cia. for the partnership.

\section{References}

Abdul-Hamid, A., Sulaiman, R. R., Osman, A., \& Saari, N. (2007). Preliminary study of the chemical composition of the rice milling fractions stabilized by microwave heating. Journal of Food Composition and Analysis, 20(7), 627-637. http://dx.doi.org/10.1016/j.jfca.2007.01.005.

Amatyakul, T., Halmos, A. L., Sherkat, F., \& Shah, N. P. (2006). Physical characteristics of yogurts made using exopolysaccharideproducing starter cultures and varying casein to whey protein ratios. International Dairy Journal, 16(1), 40-51. http://dx.doi.org/10.1016/j. idairyj.2005.01.004.

Association of Official Analytical Chemists. (2012). Official methods of analysis of the Association of Official Analytical Chemists (19th ed.) Washington: AOAC International.

Barcia, M. T., Pertuzatti, P. B., Rodrigues, D., Bochi, V. C., HermosínGutiérrez, I., \& Godoy, H. T. (2015). Effect of drying methods on the phenolic content and antioxidant capacity of Brazilian winemaking byproducts and their stability over storage. International Journal of Food Sciences and Nutrition, 66(8), 895-903. PMid:26560711. http:// dx.doi.org/10.3109/09637486.2015.1110688.

Bartz, J., Madruga, K. M., Klein, B., Pinto, V. Z., \& Dias, A. R. G. (2012). Pasting properties of native and acetylated rice starches. Brazilian Journal of Food Technology, 15(spe), 78-83.

Bezerra, M., Araujo, A., Santos, K., \& Correia, R. (2015). Caprine frozen yoghurt produced with fresh and spray dried jambolan fruit pulp (Eugenia jambolana Lam) and Bifidobacterium animalis subsp. lactis BI-07. LWT - Food Science and Technology (Campinas.), 62(2), 1099-1104.

Brand-Williams, W., Cuvelier, M. E., \& Berset, C. (1995). Use of a free radical method to evaluate antioxidant activity. $L W T$ - Food Science and Technology (Campinas.), 28(1), 25-30.

Butsat, S., \& Siriamornpun, S. (2010). Antioxidant capacities and phenolic compounds of the husk, bran and endosperm of Thai rice. Food Chemistry, 119(2), 606-613. http://dx.doi.org/10.1016/j. foodchem.2009.07.001.

Coda, R., Lanera, A., Trani, A., Gobbetti, M., \& Cagno, R. D. (2012). Yogurt-like beverages made of a mixture of cereals, soy and grape must: Microbiology, texture, nutritional and sensory properties. International Journal of Food Microbiology, 155(3), 120-127. PMid:22341935. http://dx.doi.org/10.1016/j.ijfoodmicro.2012.01.016.

Costa, K. K. F. D., Garcia, M. C., Soares Junior, M. S., \& Caliari, M. (2016). Rheological properties of fermented rice extract with probiotic bacteria and different concentrations of waxy maize starch. $L W T$ Food Science and Technology (Campinas.), 77(1), 71-77.

Cruz, A. G., Cadena, R. S., Faria, J. A. F., Bolini, H. M. A., Celeghini, R. M. S., Raices, R. S. L., Oliveira, C. A. F., Freitas, M. Q., Conte, C. A. Jr., \& Marsico, E. T. (2013). Stability of probiotic yogurt added with 
glucose oxidase in plastic materialswith different permeability oxygen rates during the refrigerated storage. Food Research International, 51(2), 723-728. http://dx.doi.org/10.1016/j.foodres.2013.01.028.

Dannerberg, F., \& Kessler, H. G. (1988). Effect of denaturation of $\beta$-lactoglobulin on texture properties of set-style nonfat yoghurt. 2. Firmness and Flow Properties. Milchwissenschaft. Milk Science International, 43(11), 700-704.

Dische, E. (1962). Color reactions of carbohydrates. In R. L. Whistler \& M. L. Wolfram, Method carbohydrates chemistry (pp. 477-512). New York: Academic.

Fagundes, U. No. (2012). Food allergy in childhood and their digestive symptoms: an increasingly prevalent disease in the modern world. The Electronic Journal of Pediatric Gastroenterology. Nutrition and Liver Diseases, 16(1), 1-52.

Hung, P. V., Maeda, T., Miyatake, K., \& Morita, N. (2009). Total phenolic compounds and antioxidant capacity of wheat graded flours by polishing method. Food Research International, 42(1), 185-190. http://dx.doi.org/10.1016/j.foodres.2008.10.005.

Illupapalayam, V. V., Smith, S. C., \& Gamlath, S. (2014). Consumer acceptability and antioxidant potential of probiotic-yogurt with spices. LWT - Food Science and Technology (Campinas.), 55(1), 255-262.

Jaekel, L. Z., Rodrigues, R. S., \& Silva, A. P. (2010). Physical-chemical and sensory drinks with different proportions of soymilk and rice. Food Science and Technology (Campinas.), 30(2), 342-348. http:// dx.doi.org/10.1590/S0101-20612010000200009.

Jaros, D., Rohm, H., Haque, A., Bonapartem, C., \& Kneifel, W. (2002). Influence of the starter culture on the relationship between dry matter content and physical properties of set-style yogurt. Milchwissenschaft. Milk Science International, 57(6), 325-327.

Lobato-Calleros, C., Ramirez-Santiago, C., Vernon-Carter, E. J., \& Alvarez-Ramirez, J. (2014). Impact of native and chemically modified starches addition as fat replacers in the viscoelasticity of reduced-fat stirred yogurt. Journal of Food Engineering, 131(1), 110-115.

Miranda, T. G., Lafetá, B. O., Dessimoni-Pinto, N. A. V., \& Vieira, G. (2012). Evaluation of strawberry syrup under different sugar concentrations and storage conditions. Brazilian of Food and Nutrition, 23(2), 307-315.

Morrison, W. R. (2005). Starch lipids and how relate to starch granule structure and functionality. Cereal Foods World, 40, 437-445.

Oliveira, K. A. M., Ribeiro, R. S., Oliveira, G. V., Pereira, J. M., Mendonça, R. C. S., \& Assumpção, C. F. (2008). Development Arataticum yogurt formulation and study of sensory acceptance. Brazilian of Food and Nutrition, 19(3), 277-281.

Prassad, L. N., Sherkat, F., \& Shah, N. P. (2013). Influence of galactooligosaccharides and modified waxy maize starch on some attributes of yogurt. Journal of Food Science, 78(1), 77-83. PMid:23278467. http://dx.doi.org/10.1111/j.1750-3841.2012.03004.x.

Re, R., Pellegrini, N., Proteggente, A., Pannala, A., Yang, M., \& RiceEvans, C. (1999). Antioxidant activity applying an improved ABTS radical cation decolorization assay. Free Radical Biology \& Medicine, 26(9-10), 1231-1237. PMid:10381194. http://dx.doi.org/10.1016/ S0891-5849(98)00315-3.
Ribeiro, E. P., \& Seravalli, E. A. G. (2007). Química de alimentos (183 p.). São Paulo: Blucher.

Sengül, M., Erkaya, T., Sengul, M., \& Yidiz, H. (2014). An investigation of the antioxidant activities and some physicochemical characteristics of strawberry added yogurt. Italian Journal of Food Science, 26(1), 235-242.

Shih, F. F. (2012). An update on the use of co-products from the milling of rice in value-added food products. Journal of the American Oil Chemists' Society, 89(1), 51-54. http://dx.doi.org/10.1007/s11746011-1941-6.

Shori, A. B., \& Baba, A. S. (2014). Comparative antioxidant activity, proteolysis and in vitro $\alpha$-amylase and $\alpha$-glucosidase inhibition of Allium sativum-yogurts made from cow and camel milk. Journal of Saudi Chemical Society, 18(5), 456-463. http://dx.doi.org/10.1016/j. jscs.2011.09.014.

Singh, J., Kaur, L., \& McCarthy, O. J. (2007). Factors influencing the physic-chemical, morphological, thermal and rheological properties of some chemically modified starches for food aplications: a review. Food Hydrocolloids, 21(1), 1-22. http://dx.doi.org/10.1016/j. foodhyd.2006.02.006.

Singleton, V. L., Orthofer, R., \& Lamuela-Raventos, R. M. (1999). Analysis of total phenols and others oxidation substrates and antioxidants by means of Folin Ciocalteau reagent. Methods in Enzymology, 299, 152-178. http://dx.doi.org/10.1016/S0076-6879(99)99017-1.

Soares, M. S. Jr., Bassinelo, P. Z., Caliari, M., Velasco, P., Reis, R. C., \& Carvalho, W. T. (2010). Flavored drinks produced broken rice extracts, rice and soybean. Ciência e Agrotecnologia, 34(2), 407-413. http://dx.doi.org/10.1590/S1413-70542010000200019.

Thamer, K. G., \& Penna, A. L. B. (2006). Characterization of functional dairy beverages fermented by probiotics and prebiotics plus. Food Science and Technology (Campinas.), 26(3), 589-595. http://dx.doi. org/10.1590/S0101-20612006000300017.

United States Department of Agriculture. (2014). Rice yearbook 2014. Washington. Retrieved from http://www.ers.usda.gov/data-products/ rice-yearbook-2014.aspx

Universidade de São Paulo. (2015). Brazilian Food Composition Table - TBCA. São Paulo. Retrieved from http://www.intranet.fcf.usp. br/tabela/

Weber, F. H., Collares-Queiroz, F. P., \& Chang, Y. K. (2009). Physicochemical, rheological, morphological, and thermal characterization of normal, waxy, and high amylose corn starches. Food Science and Technology (Campinas.), 29(4), 748-775. http://dx.doi.org/10.1590/S010120612009000400008

Ye, M., Ren, L., Wu, Y., Wang, Y., \& Liu, Y. (2013). Quality characteristics and antioxidant activity of hickory-black soybean yogurt. $L W T$ - Food Science and Technology (Campinas.), 51(1), 314-318.

Zhao, D., \& Shah, N. P. (2014). Changes in antioxidant capacity, isoflavone profile, phenolic and vitamin contents in soymilk during extended fermentation. LWT - Food Science and Technology (Campinas.), $58(2), 454-462$. 